\title{
Evaluation of molecular diversity of central European maize cultivars
}

\author{
Želmíra Balážová*, Martin Vivodík, Zdenka Gálová \\ Slovak University of Agriculture in Nitra, Faculty of Biotechnology and Food Sciences, Department of Biochemistry and Biotechnology, \\ Tr. A. Hlinku 2, 949 76, Nitra, Slovak Republic
}

\section{A B S T R A C T}

\begin{abstract}
In the present study, random amplified polymorphic DNA (RAPD) markers were used to assess genetic diversity of the maize genotypes from Central European countries and Union of Soviet Socialist Republics. Thirteen arbitrary random primers were used to determine RAPD polymorphism in the set of forty maize genotypes. Amplification of genomic DNA of 40 genotypes, using RAPD analysis, yielded 92 fragments, with an average of 7.08 polymorphic fragments per primer. Number of amplified fragments ranged from 5 (OPA-02, OPB-08, OPD-07) to 10 (OPA-13), with the size of amplicons ranging from 100 to $2500 \mathrm{bp}$. The polymorphic information content (PIC) value ranged from 0.709 (OPB-08) to 0.872 (OPA-13), with an average of 0.801 and index diversity (DI) value varied from 0.718 (OPB-08) to 0.874 (OPA-13) with an average of 0.808 . The dendrogram based on hierarchical cluster analysis using UPGMA algorithm was prepared. The hierarchical cluster analysis divided maize genotypes into 2 main clusters. In the first cluster were included 2 genotypes (Mikulická and Aranyozon sarga lofogu) from Czechoslovakia and Hungary, respectively. Second cluster was subdivided in two subclusters (2a and 2b). Subcluster $2 a$ contained two genotypes of different origin and subcluster $2 b$ was further subdivided into two subclusters, subcluster 2 ba with two genotypes and subcluster $2 \mathrm{bb}$ with 34 maize genotypes. Two genotypes of 2 bb subcluster (Kostycevskaja and Mindszentpusztai Sarga Lofogu) from former Union of Soviet Socialist Republics and Hungary, respectively, were genetically the closest. Clustering only partially reflected geographic origin of studied maize genotypes. In this experiment, RAPD proved to be a rapid, reliable and practicable method for revealing of polymorphism in the maize cultivars.
\end{abstract}

Key words: Dendrogram; Genetic variability; Molecular markers; Random primers; Zea mays L

\section{INTRODUCTION}

Maize (Zea mays) is one of the world's most important crop plants after wheat and rice, which provides staple food to large number of human population in the world (Ahmad et al., 2011). It is belonging to the family of Poaceae. In developing countries maize is a major source of income to many farmers (Tagne et al., 2008). The genetic diversity observed across landraces is the most important part of maize biodiversity, and local races represent an important fraction of the genetic variability exhibited by this genus. However, few agronomic and genetic data exist for such collections, and this scarcity has limited the use, management, and conservation of this germplasm. In addition, a few improved genotypes with narrower genetic variability are quickly replacing maize landraces (Pollack, 2003).

Since 1990, random amplified polymorphic DNA (RAPD) markers have been successfully applied for identification of DNA polymorphism in various plant species (Williams et al., 1990). They are often used for screening of a wide range of genetic stocks in order to find linkage with traits of agronomic significance (Masojć et al., 2001).

RAPD technique requires only small amounts of DNA sample without involving radioactive labels and are simpler as well as faster. RAPD has proven to be quite efficient in detecting genetic variations and used for diversity assessment and for identifying germplasm in a number of plant species (Gajeraa et al., 2010; El Kichaoui et al., 2013; Srivashtav et al., 2013; Omalsaad et al., 2014; Vivodík et al., 2014; Žiarovská et al., 2014). Suitability of RAPD markers for the construction of genetic maps, fingerprinting and phylogenetic studies has been proved by many authors. In cereal crops, such as wheat (Saleh, 2012; Bibi et al., 2012; Cifci et al., 2012), barley (Bakht et al., 2011), rye (Persson et al., 2002; Petrovičová et al., 2014), the technique has been applied to identify cultivars and revealing phylogenetic

\footnotetext{
*Corresponding author:

Martin Vivodík, Slovak University of Agriculture in Nitra, Faculty of Biotechnology and Food Sciences, Department of Biochemistry and Biotechnology, Tr. A. Hlinku 2, 949 76, Nitra, Slovak Republic. Phone: +421 37641 4269, E-mail: vivodikmartin@gmail.com
} 
relationships among them. In the case of maize, there are a lot of papers (Osipova et al., 2003; Carvalho et al., 2004, Asif et al., 2006; Bruel et al., 2007, Abuali et al., 2011, AlBadeiry et al., 2013, Molin et al., 2013) that have reported the application of the RAPD marker technique for maize molecular identification, and the technique was proved to be effective for or verification of purity and would improve the efficiency of breeding programmes (Asif et al., 2006).

The aim of this study was to detect genetic variability among the set of 40 maize genotypes using 13 RAPD markers and to testify an usefulness of chosen RAPD markers for genetic diversity study.

\section{MATERIAL AND METHODS}

\section{Plant material and extraction of genomic DNA}

Maize genotypes (40) were obtained from the Gene Bank VURV Praha-Ruzine (Czech Republic) and from the Gene Bank in Piest'any, the Slovak Republic (Table 1). Genomic DNA was isolated from the 14 days leaves with GeneJET Plant Genomic DNA Purification Mini Kit according to the manufacturer's instructions.

\section{RAPD amplification and gel electrophoresis}

Amplification of RAPD fragments was performed according to Gajeraa et al. (2010) (Table 2) using decamer arbitrary primers (Operon technologies Inc, USA; SIGMA-D, USA). Polymerase chain reactions (PCR) were carried out in $25 \mu$ l of following mixture: $10.25 \mu$ l deionized water, $12.5 \mu$ l Master Mix (Promega, USA), $1.25 \mu$ l of genomic DNA, $1 \mu \mathrm{l}$ of $10 \mathrm{pmol}$ of primer. Amplification was performed in a thermocycler (Biometra, Germany) with initial denaturation at $94{ }^{\circ} \mathrm{C}$ for $5 \mathrm{~min}, 42$ cycles of denaturation at $94{ }^{\circ} \mathrm{C}$ for $1 \mathrm{~min}$, primer annealing at $38^{\circ} \mathrm{C}$ for $1 \mathrm{~min}$, extension at $72^{\circ} \mathrm{C}$ for $1 \mathrm{~min}$, and final extension at $72{ }^{\circ} \mathrm{C}$ for $5 \mathrm{~min}$. Amplified products were separated in $1.5 \%$ agarose in $1 \times$ TBE buffer. The gels were stained with ethidium bromide and documented using gel documentation system Grab-It 1D pre Windows.

\section{Data analysis}

The RAPD bands were scored as present (1) or absent (0), each of which was treated as an independent character regardless of its intensity. A dendrogram based on hierarchical cluster analysis using the unweighted pair group method with arithmetic average (UPGMA) with the SPSS professional statistics version 17 software package was constructed. For the assessment of the polymorphism between genotypes maize and usability RAPD markers in their differentiation we used diversity index (DI) (Weir, 1990), the probability of identity (PI) (Paetkau et al., 1995) and polymorphic information content (PIC) (Weber, 1990).
Table 1: List of 40 analyzed genotypes of maize

\begin{tabular}{|c|c|c|}
\hline Genotypes & Country of origin & $\begin{array}{c}\text { Year of } \\
\text { registration }\end{array}$ \\
\hline 1. Feheres Sarga Filleres & Hungary & 1965 \\
\hline 2. Mindszentpusztai Feher & Hungary & 1964 \\
\hline 3. Zakarpatskaja & $\begin{array}{l}\text { Union of Soviet } \\
\text { Socialist Republics }\end{array}$ & 1964 \\
\hline 4. Przebedowska Burskynowa & Poland & 1964 \\
\hline 5. Krasnodarskaja & $\begin{array}{l}\text { Union of Soviet } \\
\text { Socialist Republics }\end{array}$ & 1964 \\
\hline 6. Mesterhazy Sarga Simaszemu & Hungary & 1964 \\
\hline 7. Slovenska biela perlova & Czechoslovakia & 1964 \\
\hline 8. Zuta Brzica & Yugoslavia & 1975 \\
\hline 9. Zloty Zar & Poland & 1964 \\
\hline 10. Slovenska Florentinka & Czechoslovakia & 1964 \\
\hline 11. C.44 Juhoslavska & Yugoslavia & 1964 \\
\hline 12. Kostycevskaja & $\begin{array}{l}\text { Union of Soviet } \\
\text { Socialist Republics }\end{array}$ & 1964 \\
\hline $\begin{array}{l}\text { 13. Mindszentpusztai Sarga } \\
\text { Lofogu }\end{array}$ & Hungary & 1964 \\
\hline 14. Stodnova & Czechoslovakia & 1964 \\
\hline 15. Slovenska žltá & Slovak Republic & 1964 \\
\hline 16. Slovenska krajová velkozrná & Slovak Republic & 1964 \\
\hline 17. Partizanka & $\begin{array}{l}\text { Union of Soviet } \\
\text { Socialist Republics }\end{array}$ & 1964 \\
\hline 18. Voroneskaja & $\begin{array}{l}\text { Union of Soviet } \\
\text { Socialist Republics }\end{array}$ & 1964 \\
\hline 19. Kocovska Skora & Slovak Republic & 1964 \\
\hline 20. Milada & Czechoslovakia & 1964 \\
\hline 21. Moldavskaja & $\begin{array}{l}\text { Union of Soviet } \\
\text { Socialist Republics }\end{array}$ & 1964 \\
\hline 22. Bučiansky Konský Zub & Slovak Republic & 1964 \\
\hline 23. Hodoninský konský zub žltý & Czechoslovakia & 1964 \\
\hline 24. M Silokukurica & Hungary & 1964 \\
\hline 25. Valticka & Czechoslovakia & 1964 \\
\hline 26. Przebedowska Biala & Poland & 1964 \\
\hline 27. Toschevska & Slovak Republic & 1964 \\
\hline 28. Šamorinsky konský zub & Hungary & 1964 \\
\hline 29. Wielkopolanka & Poland & 1964 \\
\hline 30. Czechnicka & Poland & 1964 \\
\hline 31. Manalta & Czechoslovakia & 1964 \\
\hline 32. Zlota gorecka & Poland & 1964 \\
\hline 33. Celchovicka ADQ & Czechoslovakia & 1964 \\
\hline 34. Belaja mestnaja & $\begin{array}{l}\text { Union of Soviet } \\
\text { Socialist Republics }\end{array}$ & 1964 \\
\hline 35. Bučanská žltá & Slovak Republic & 1964 \\
\hline 36. Iregszemeseil 2 hetes & Hungary & 1964 \\
\hline 37. Dnepropetrovskaja & $\begin{array}{l}\text { Union of Soviet } \\
\text { Socialist Republics }\end{array}$ & 1964 \\
\hline 38. Bezuncukskaja & $\begin{array}{l}\text { Union of Soviet } \\
\text { Socialist Republics }\end{array}$ & 1964 \\
\hline 39. Mikulická & Czechoslovakia & 1964 \\
\hline 40. Aranyozon sarga lofogu & Hungary & 1964 \\
\hline
\end{tabular}

\section{RESULTS AND DISCUSSION}

Our study dealt with detection of genetic polymorphism in maize cultivars using RAPD markers. For the differentiation of forty maize genotypes thirteen RAPD markers (Table 1) 
were chosen according to Gajeraa et al. (2010). PCR amplifications using 13 RAPD primers produced 92 DNA fragments that could be scored in all genotypes (Figure 1). Chosen primers amplified DNA fragments across 40 maize genotypes studied, with the number of amplified fragments ranged from 5 (OPA-02, OPB-08, OPD-07) to 10 (OPA-13), and the amplicon size varying from 100 to $2500 \mathrm{bp}$. Of the 92 amplified bands, all 92 were polymorphic, with an average of 7.08 polymorphic bands per primer. The polymorphic information content (PIC) values varied from 0.709 (OPB-08) to 0.872 (OPA-13), with an average of 0.801 and index diversity (DI) value varied from 0.718 (OPB-08) to 0.874 (OPA-13) with an average of 0.808 (Table 3).

Similar values of DI and the PIC were detected by other authors (Osipova et al., 2003; De Vasconcelos et al., 2008; Mukharib et al., 2010; Al-Badeiry et al., 2013; Molin et al., 2013; Mrutu et al., 2014) and these values presented a

Table 2: List of RAPD primers

\begin{tabular}{llc}
\hline Primers & $\begin{array}{l}\text { Primer sequence } \\
\left(5^{\prime} \mathbf{- 3}^{\prime}\right)\end{array}$ & $\begin{array}{c}\text { Molecular weight } \\
\text { range } \mathbf{( b p )}\end{array}$ \\
\hline OPA-02 & TGCCGAGCTG & $300-2000$ \\
OPA-03 & AGTCAGCCAC & $250-900$ \\
OPA-13 & CAGCACCCAC & $400-2000$ \\
OPB-08 & GTCCACACGG & $400-1700$ \\
OPD-02 & GGACCCAACC & $500-2000$ \\
OPD-07 & TTGGCACGGG & $200-1000$ \\
OPD-08 & GTGTGCCCCA & $300-1700$ \\
OPD-13 & GGGGTGACGA & $100-1500$ \\
OPE-07 & AGATGCAGCC & $200-1300$ \\
OPF-14 & TGCTGCAGGT & $150-2500$ \\
SIGMA-D-01 & AAACGCCGCC & $300-2000$ \\
SIGMA-D-14 & TCTCGCTCCA & $400-800$ \\
SIGMA-D-P & TGGACCGGTG & $200-2500$ \\
\hline
\end{tabular}

Table 3: The statistical characteristics of the RAPD markers used in maize

\begin{tabular}{lcccc}
\hline Primers & Number of alleles & DI & PIC & PI \\
\hline OPA-02 & 5 & 0.768 & 0.755 & 0.041 \\
OPA-03 & 7 & 0.826 & 0.820 & 0.007 \\
OPA-13 & 10 & 0.874 & 0.872 & 0.006 \\
OPB-08 & 5 & 0.718 & 0.709 & 0.032 \\
OPD-02 & 6 & 0.765 & 0.751 & 0.049 \\
OPD-07 & 5 & 0.725 & 0.723 & 0.026 \\
OPD-08 & 8 & 0.834 & 0.829 & 0.006 \\
OPD-13 & 9 & 0.856 & 0.849 & 0.005 \\
OPE-07 & 7 & 0.835 & 0.829 & 0.006 \\
OPF-14 & 8 & 0.865 & 0.862 & 0.003 \\
SIGMA-D-P & 7 & 0.839 & 0.833 & 0.005 \\
SIGMA-D-01 & 8 & 0.854 & 0.849 & 0.004 \\
SIGMA-D-14 & 7 & 0.741 & 0.728 & 0.023 \\
Average & 7.08 & 0.808 & 0.801 & 0.016 \\
\hline
\end{tabular}

DI: Diversity index; PIC: Polymorphic information content; PI: Probability of identity high level of polymorphism of maize genotypes detected by RAPD markers. Our results based on the values of DI and PIC showed that RAPD markers are suitable marker system to distinguish maize genotypes.

Osipova et al. (2003) used RAPD markers to analyse the genetic divergence between the regenerated plants derived from callus cultures and the original maize line A188. Specific polymorphism revealed with random primers was completely confirmed using five SCAR markers. De Vasconcelos et al. (2008) used the RAPD technique to evaluate somaclonal variation in maize plants derived from tissue culture from the maize inbred line L48 (derived from Suwan). Forty seven different decamer oligonucleotide primers generated 221 amplification products, 130 of them being polymorphic.

Al-Badeiry et al. (2013) used RAPD markers to fingerprint 20 varieties of maize. Twenty operon primers generated informative RAPD patterns and selected for further RAPD analysis. The largest number of polymorphic bands (20 bands) was produced by primer OPX-04 while, the lowest number of polymorphic bands (1 band) was produced by primer OPA-03. The primers of the most interest of this purpose were those that produced more variety specific DNA profiles, such as OPD-03, OPE-18, OPF-05, OPL-11 and OPX-04. In our study we have detected 7 polymorphic alleles by primer OPA-03. Much higher number of alleles (7) compared to Al-Badeiry et al. (2013), who detected only one allele, can be caused by diverse set of maize varieties used for analysis. Mrutu et al. (2014) assessed the genetic diversity of maize hybrids grown in Southern highlands of Tanzania by using RAPD markers. Twelve maize samples (six inbreds and six hybrids) were collected and used in this study. A total of 123 bands were produced of which $98(80 \%)$ were polymorphic.

The aim of Molin et al. (2013) was to estimate the genetic diversity across 48 varieties of maize landraces cultivated at different locations in the States of Rio Grande do Sul (RS) and Paraná (PR) by means of different marker system including random amplified polymorphic DNA (RAPD). Maize landrace accessions were genotyped using the 30 RAPD primers. RAPD analysis resulted in amplification of 335 fragments polymorphic fragments and a polymorphic index of $81.9 \%$. Similar level of polymorphism (84.44\%) obtained also Bruel et al. (2007).

A dendrogram prepared based on hierarchical cluster analysis using UPGMA algorithm separated 40 maize genotypes into two clusters. First cluster contained two maize genotypes Mikulická and Aranyozon sarga lofogu. from Czechoslovakia and Hungary, respectively. Second cluster was subdivided in two subclusters ( $2 \mathrm{a}$ and $2 \mathrm{~b}$ ). 
Subcluster 2a contained two genotypes of different origin from former Czechoslovakia and Yugoslavia, and subcluster $2 \mathrm{~b}$ was further subdivided into two subclusters, subcluster 2ba with two genotypes from Slovakia and former Union of Soviet Socialist Republics, and subcluster $2 \mathrm{bb}$ with
34 maize genotypes. Two genotypes of $2 \mathrm{bb}$ subcluster (Kostycevskaja and Mindszentpusztai Sarga Lofogu) from former Union of Soviet Socialist Republics and Hungary, were genetically the closest (Fig 2). Dendrogram partially reflects the country of origin of studied maize genotypes.

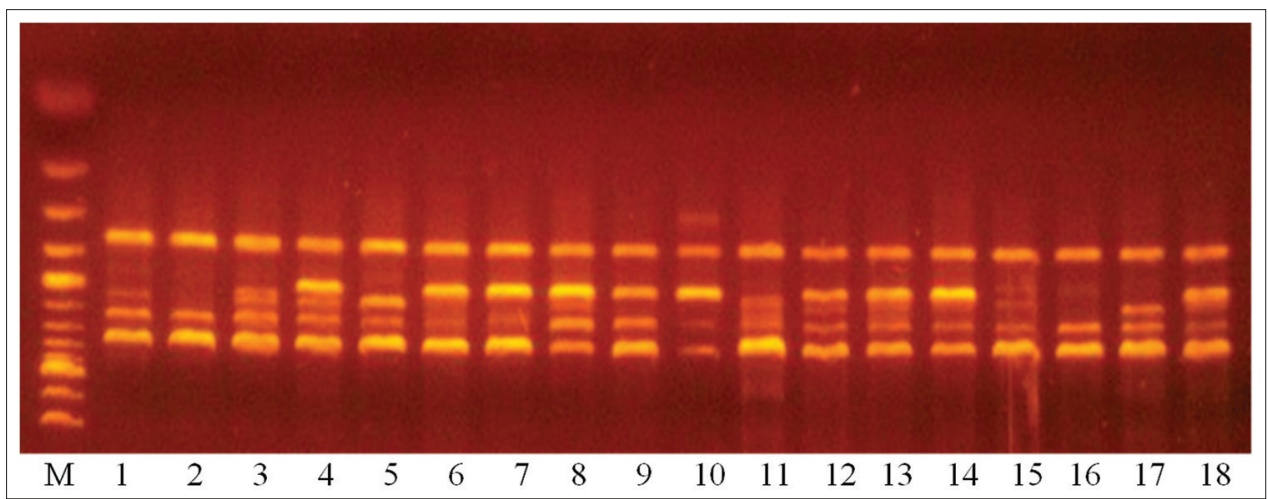

Fig 1. PCR amplification products of 18 genotypes of mayze produced with RAPD primer OPA-02. Lane M is 1-kb DNA ladder and lanes $1-18$ are maize genotypes (Table 2 ).

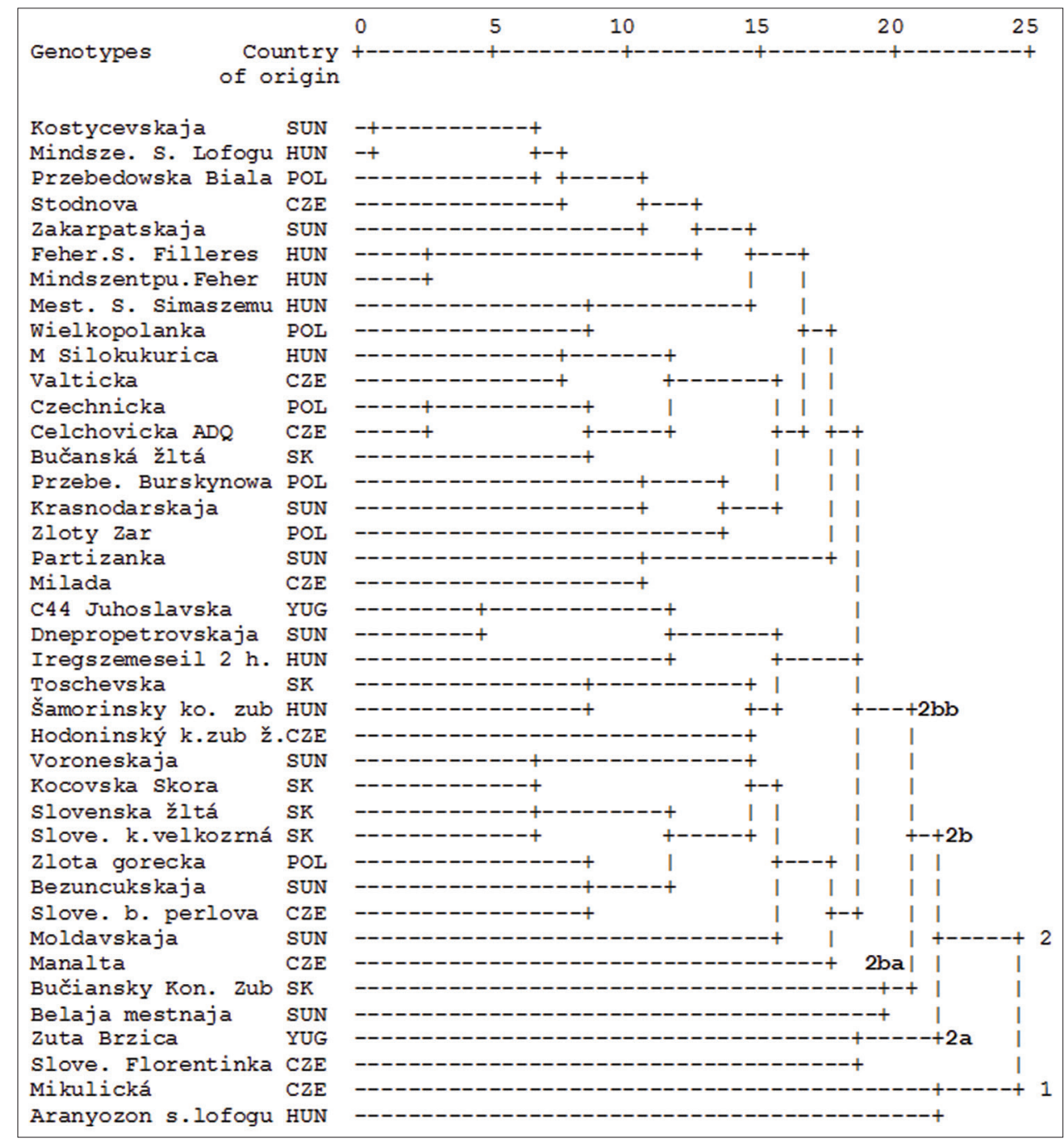

Fig 2. Dendrogram of 40 maize genotypes prepared based on 13 RAPD markers. CZE - Czechoslovakia, HU - Hungary, POL - Poland, SUN - Union of Soviet Socialist Republics, SK - Slovakia, YUG - Yugoslavia 
De Vasconcelos et al. (2008) based on cluster analyses divided the maize samples into three distinct groups, considering an upper limit of 0.38 genetic distances. Molin et al. (2013) using 30 RAPD primers studied the genetic diversity across 48 varieties of maize landraces cultivated at different locations in the States of Rio Grande do Sul (RS) and Paraná (PR) by means of different marker system including random amplified polymorphic DNA (RAPD). Regarding the RAPD dendrogram, groups comprising accessions from RS prevailed, whereas SSR comprised varieties from both collection sites. Mrutu et al. (2014) based on RAPD analysis assessed the genetic diversity of maize hybrids grown in Southern highlands of Tanzania. The range of genetic similarity of the studied samples calculating based on Jaccard's similarity coefficient was from 0.32 to 0.95 . The UPGMA analysis indicated higher similarity between the hybrids than the inbreds. Bruel et al. (2007) constructed dendrogram using UPGMA clustering method. They found out that 16 lines separated into five distinct groups, which were in agreement with the heterotic patterns described based on the genealogy of the lines.

RAPD molecular markers have been used in population genetic studies (Žiarovská et al., 2013; Pawar et al., 2013; Petrovičová et al., 2014; Kallamadi et al., 2015). Some researchers have considered RAPD markers to represent segments of DNA with noncoding regions and to be selectively neutral (Vivodík et al., 2014), and some studies have shown that RAPD markers are distributed throughout the genome and may be associated with functionally important loci (Penner, 1996).

\section{CONCLUSION}

The analysis showed that the RAPD markers are very effective molecular markers for the assessment of the genetic diversity in maize and for differentiation of a set of maize genotypes. A dendrogram based on UPGMA analysis separated 40 maize genotypes into two subclusters. The primers used in our analysis recorded 100 per cent polymorphism. RAPD markers can be used to identify diverse sources in crop germplasm collections or to select groups of genotypes with desirable characters and contrasting phenotypes, if large number are employed. RAPD markers are useful in the assessment of maize diversity, the detection of duplicate sample in genotypes collection, and the selection of a core collection to enhance the efficiency of genotypes management for use in maize breeding and conservation.

\section{ACKNOWLEDGMENTS}

This work was funded by European Community under project No. 26220220180: Building Research Centre
"AgroBioTech" (50\%) and KEGA project No 021SPU$4 / 2015(50 \%)$.

\section{AUTHOR CONTRIBUTIONS}

M. V.: was responsible for the molecular analysis and paper writing. $\check{Z}$. B.: was involved in molecular analysis and evaluating of the results and reviewed the paper. Z. G.: supervised the research.

\section{REFERENCES}

Abuali, A. I., A. A. Abdelmula and M. M. Khalafalla. 2011. Assessment of genetic diversity in Sudanese maize (Zea mays L.) genotypes using random amplified polymorphic DNA (RAPD) markers. Afr. J. Biotechnol. 10(42): 8245-8250.

Ahmad, S., S. Khan, M. Ghaffar and F. Ahmad. 2011. Genetic diversity analysis for yield and other parameters in maize (Zea mays L.) genotypes. Asian J. Agric. Sci. 3(5): 385-388.

Al-Badeiry, N. A. H., T. K. Merza and A. H. Al-Saadi. 2013. Assessment of genetic diversity and relationships among maize (Zea mays L.) Varieties in iraq using random amplified polymorphic DNA (RAPD) markers. J. Life Sci. 7(12): 1260-1271.

Asif, M., Mehboob-Ur-Rahman and Y. Zafar. 2006. Genotyping analysis of six maize (Zea Mays L.) hybrids using dna fingerprinting technology. Pak. J. Bot. 38(5): 1425-1430.

Bakht, J., M. Ghaffar, M. Shafi, S. Khan and B. Latif. 2011. Determination of genetic diversity of different barley genotypes grown in Khyber Pakhtun Khwa province using RAPD markers. Pak. J. Bot. 43(5): 2491-2495.

Bibi, S., I. A. Khan, I. A. Dahot, A. Khatri, M. H. Naqvi, M. A. Siddiqui, S. Yasmeen and N. Seema. 2012. Estimation of genetic variability among elite wheat genotypes using random amplified polymorphic DNA (RAPD) analysis. Pak. J. Bot. 44(6): 20332040.

Bruel, D. C., V. Carpentieri-Pípolo, C. F. Ruas, A. C. Gerage and S. G. H. de Souza. 2007. Assessment of genetic diversity in maize inbred lines using RAPD markers. Crop Breed. Appl. Biotechnol. 7: 173-178.

Cifci, E. A. and Yagdi, K. 2012. Study of genetic diversity in wheat (Triticum aestivum) varieties using random amplified polymorphic DNA (RAPD) analysis. Turk. J. Field Crops. 17(1): 91-95.

Carvalho, V. P., C. F. Ruas, J. M. Ferreira, R. M. P. Moreira and P. M. Ruas. 2004. Genetic diversity among maize (Zea mays L.) landraces assessed by RAPD markers. Genet. Mol. Biol. 27(2): 228-236.

De Vasconcelos, M. J. V., M. S. Antunes, S. M. Barbosa and C. H. S. De Carvalho. 2008. RAPD analysis of callus regenerated and seed grown plants of maize (Zea mays L.). Rev. Bras. Milho e Sorgo. 7(2): 93-104.

El Kichaoui, A., M. A. Abu Zayed and B. M. Ayesh. 2013. Genotyping and identification of six date palm (Phoenix dactylifera L.) cultivars of the gaza strip by random amplification of polymorphic DNA. Emir. J. Food Agric. 25(11): 916-925.

Gajeraa, B. B., N. Kumara, A. S. Singha, B. S. Punvara, R. Ravikirana, N. Subhasha and G. C. Jadejab. 2010. Assessment of genetic diversity in castor (Ricinus communis L.) using RAPD and ISSR markers. Ind. Crops Prod. 32: 491-498.

Kallamadi, P. R., V. P. R. Ganga Rao Nadigatlab and S. Mulpurib. 
2015. Molecular diversity in castor (Ricinus communis L.). Ind. Crops Prod. 66: 271-281.

Kilian, A., E. Huttner, P. Wenzl, D. Jaccoud and J. Carling. 2005. The fast and the cheap: SNP and DArT-based whole genome profiling for crop improvement. In: Tuberosa, R., R. L. Phillips. and M. Gale, (Eds.), Proceedings of the International Congress in the Wake of the Double Helix: From the Green Revolution to the Gene Revolution, Vol. 27. Bologna. Pp. 443-461.

Masojc', P., B. Mysków and P. Milczarski. 2001. Extending a RFLPbased genetic map of rye using random amplified polymorphic DNA (RAPD) and isozyme markers. Theor. Appl. Genet. 102(8): 1273-1279.

Molin, D., C. J. Coelho, D. S. Máximo, F. S. Ferreira, J. R. Gardingo and R. R. Matiello. 2013. Genetic diversity in the germplasm of tropical maize landraces determined using molecular markers. Genet. Mol. Res. 12(1): 99-114.

Mrutu, B. A., T. Feyissa and J. Ndunguru. 2014. Assessment of genetic diversity of maize inbred lines and hybrids in Southern Highlands of Tanzania by using Random amplified Polymorphic DNA (RAPD) markers. Am. J. Res. Commun. 2(4): 84-99.

Mukharib, D. S., V. C. Patil, D. P. Biradar, P. M. Salimath and V. P. Chimmad. 2010. Assessment of molecular diversity in selected maize inbreds. Karnataka J. Agric. Sci. 23(3): 409-412.

Mullis, K. B. and F. A. Faloona. 1987. Specific synthesis of DNA in vitro via a polymerase-catalyzed chain reaction. Methods Enzymol. 155: 335-350.

Omalsaad, A. K. M., A. Islam, M. A. Jahan, Z. Yaakob and M. Osman. 2014. Genetic relationship between roselle (Hibiscus sabdariffa L.) and kenaf (Hibiscus cannabinus L.) accessions through optimization of PCR based RAPD method. Emir. J. Food Agric. 26(3): 247-258.

Osipova, E. S., O. V. Koveza, A. V. Troitskij, Y. I. Dolgikh, Z. B. Shamina and S. A. Gostimskij. 2003. Analysis of specific RAPD and ISSR fragments in maize (Zea mays L.) somaclones and development of SCAR markers on their basis. Russ. J. Genet. 39(12): 1412-1419.

Paetkau, D., W. Calvert, I. Stirling and C. Strobeck. 1995. Microsatellite analysis of population structure in Canadian polar bears. Mol. Ecol. 4: 347-354.

Pawar, U. R., J. Baskaran, I. P. Ajithkumar and R. Panneerselvam. 2013. Genetic variation between Xylocarpus spp. (Meliaceae) as revealed by random amplified polymorphic DNA (RAPD) markers. Emir. J. Food Agric. 25(8): 597-604.
Penner, G. A. 1996. RAPD analysis of plant genomes. In: Jauhar, P.P. (Ed.), Methods of Genome Analysis in Plants. CRC, Boca Raton, Pp. 251-268.

Persson, K. and B. Von Bothmer. 2002. Genetic diversity in landraces of rye (Secale cereale L.) from Northern part of Europe by using allozymes. Hereditas, 136(1): 29-38.

Petrovičová, L., Z. Gálová, Ž. Balážová, M. Vivodík, M. Wójcik-Jagla and M. Rapacz. 2014. Genetic Diversity of Czechoslovak Origin Rye Cultivars Detected by RAPD Markers, CECE 2014. Institute of Analytical Chemistry ASCR, Brno, Pp. 353-356.

Pollack, L. M. 2003. The history and success of the public-private project on germplasm enhancement of maize (GEM). Adv. Agron. 78: 45-87.

Saleh, B. 2012. Biochemical and genetic variation of some syrian wheat varieties using NIR, RAPD and AFLPs techniques. J. Plant Biol. Res. 1(1): 1-11.

Srivashtav, V. S., C. V. Kapadia, M. K. Mahatma, S. K. Jha, S. Jha and T. Ahmad. 2013. Genetic diversity analysis of date palm (Phoenix dactylifera L.) in the Kutch region of India using RAPD and ISSR markers. Emir. J. Food Agric. 25(11): 907-915.

Tagne, A., T. P. Feujio and C. Sonna. 2008. Essential oil and plant extracts as potential substitutes to synthetic fungicides in the control of fungi. International Conference Diversifying Crop Protection, La Grande-Motte, France, Pp. 12-15.

Vivodík, M., Ž. Balážová and Z. Gálová. 2014. RAPD analysis of the genetic diversity of castor bean. Int. J. Biol. Vet. Agric. Food Eng. 8(7): 583-586

Žiarovská, J., K. Ražná and M. Labajová. 2013. Using of inter microsatellite polymorphism to evaluate gamma-irradiated Amaranth mutants. Emir. J. Food Agric. 25(9): 673-681.

Žiarovská, J., M. Bežo, M. Hrdlicková and E. Fernandéz. 2014 Standardization and reproducibility of random marker based analysis of micropropagated crimson beebalm. Genetika, 46(3): 855-864.

Weber, J. L. 1990. Informativeveness of human (dC-dA)n x (dG-dT)n polymorphism. Genomics. 7: 524-530.

Weir, B. S. 1990. Genetic Data Analysis. Methods for Discrete Population Genetic Data, Sinauer Associates Incorporated, Massachussetts, Pp. xii-377.

Williams, J. G. K., A. R. Kubelik, K. J. Livak, J. A. Rafalski and S. V. Tingey. 1990. DNA polymorphisms amplified by arbitrary primers are useful as genetic markers. Nucleic Acids Res. 18: 6531-6535. 